\title{
Cds and Cdse Quantum Dot Solar Cells Production and Improving Efficiency of the Cells by Ion-Doped Quantum Points Cds Holmium
}

\author{
Ghasem Rezanejad Bardajee*, Alireza Adl and Samaneh Sadat Hosseini \\ Department of Chemistry, Iran
}

Received: 制: November 08, 2018; Published: 制: November 26, 2018

*Corresponding author: Ghasem Rezanejad Bardajee, Department of Chemistry, Tehran, Iran

\begin{abstract}
This project aims to improve the efficiency of solar cells doped by CdS quantum dot and $\mathrm{Ho}^{+3}$ ion. Successive Ionic Layer Absorption and Reaction (SILAR) and Chemical Bath Deposition method (CBD), were used to deposit a CdS/CdSe layer on TiO2 film. According to J-V diagram, it is concluded that adding holmium ions $\left(\mathrm{Ho}^{3+}\right)$ will enhance the efficiency of quantum dot sensitized solar cells up to $2.53 \%$.

Keywords: Solar Cells; Quantum Dots; Holmium

Abbreviations: QD: Quantum Dots; SILAR: Successive Ionic Layer Absorption and Reaction; CBD: Chemical Bath Deposition Method; MEG: Multiple Excitation Generation; EIS: Electrochemical Impedance Spectroscopy; XRD: X-ray Diffraction; FTO: Fluorine Doped Tin Oxide
\end{abstract}

\section{Introduction}

Nowadays, energy issues have been challenged as the most important human necessities. In the meantime solar or photovoltaic cells have been attended in order to transferring of solar energy to electricity in which solar energy has been used as a clean, unexpansive and available energy source [1-3]. Solar cells are divided into different types such as dye sensitized, silicone solar cells, molecular, GaAs and quantum dots (QD) [4, 5]. Recently, QD solar cells have attracted great attention because of their low cost, high surface area and more quantum yield [6-8]. In QDs, Multiple excitation generation properties (MEG) cause a few electron transfers from valance band to conductive band by incident of just one photon which increases absorption in solar cell and finely leads to high performance of solar cell [9]. Some QDs are used in preparation of solar cells such as: InAs, $\mathrm{CdTe}, \mathrm{PbS}$, InPO ${ }_{4}$, CdS, CdSe, etc. Using CdS and CdSe simultaneously has a good effect on emission of light because of increasing of band gap via a synergic effect [10-12]. There are some methods for deposition of QDs onto $\mathrm{TiO}_{2}$ like chemical bath deposition (CBD), SILAR and hot injection growth method. In cathode electrode, $\mathrm{Pt}$ or $\mathrm{Cu}_{2} \mathrm{~S}$ is used which because of high cost of Pt using the $\mathrm{Cu}_{2} \mathrm{~S}$ is more popular and common $[13,14]$. In order to increase electron injection from $\mathrm{QD}$ to $\mathrm{TiO}_{2}$, coating a layer of $\mathrm{ZnS}$ has a great effect via omitting surface-nods made on $\mathrm{TiO}_{2}$ that this layer improves quality and efficiency of solar cells. In many inves tigations, $\mathrm{I}^{-} / \mathrm{I}_{3}^{-}$solution is used as electrolyte. However, because of corrosion of solar cells by this redox complex solution, polysulfide solution $\mathrm{S}^{2-} / \mathrm{Sx}^{2-}$ is used as a substitute electrolyte.

A new method for improving the solar cell performance is introducing some metals such as $\mathrm{Mn}, \mathrm{Ni}, \mathrm{Ag}$, Cd etc to cells [15-18]. In this work existence of $\mathrm{Ho}^{3+}$ ion in QDSCS cells was used for the first time in order to improvement in photovoltaic performance of QDSCS (Figure 1).

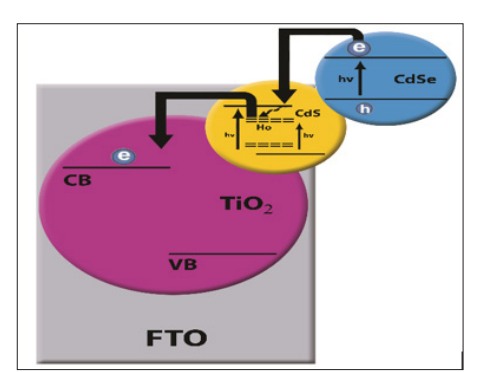

Figure 1: Schematic of the $\mathrm{FTO} \mathrm{TiO}_{2} / \mathrm{CdS}$ : $\mathrm{Ho} / \mathrm{CdSe}$ electronic structure. Direct arrows indicate the electron hole photogeneration. Dashed arrow indicates the electron transfer from CdS CB to the midgap electronic states and direct curved arrows are related to electron transfer from CdSe to CdS QDs and from CdS trap states to $\mathrm{TiO}_{2} \mathrm{CB}$. 


\section{Experimental Section}

Apparatus: SEM-EDX model Irost was applied for. Solar simulator model SIM800. Bath-Ultrasonic model (Sonica). Water purification system model No. F3JN94307E. Electrochemical Impedance Spectroscopy (EIS) was performed on IM6ex Electrochemical Workstation (ZAHNER) over a frequency range of $\left(1 \times 10^{5}-1 \times 10^{-1}\right)$ $\mathrm{Hz}$ with $10 \mathrm{mV}$ ac amplitude under forward bias of $(-0.6) \mathrm{V}$ in the dark. Formation of cells by ion-doped quantum points CdS holmium were analyzed by means of a Philips X-ray diffraction (XRD) equipfped. The XRD data were collected in the scale of $2 \theta=$ $10-80^{\circ}$ a scanning speed of $3^{\circ} \mathrm{min}^{-1}$.

Materials: Cadmium nitrate tetrahydrate $\left(\mathrm{Cd}\left(\mathrm{NO}_{3}\right)_{2} \cdot 4 \mathrm{H}_{2} \mathrm{O}\right.$, Alfa Aesar, 98.5\%), Sodium sulfide nonahydrate $\left(\mathrm{Na}_{2} \mathrm{~S} .9 \mathrm{H}_{2} \mathrm{O}\right.$, aladdin,

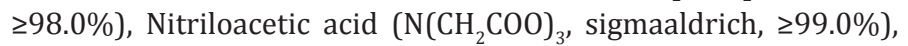
Copper(II) sulfate pentahydrate $\left(\mathrm{CuSO}_{4} \cdot 5 \mathrm{H}_{2} \mathrm{O}\right.$, sigmaaldrich, 99.99\%), Holmium (III) hexahydrate $\left(\mathrm{HoCl}_{3} \cdot 6 \mathrm{H}_{2} \mathrm{O}\right.$, sigmaaldrich, 99.9\%), Sodium hydroxide ( $\mathrm{NaOH}$, Merck, 99.0\%), Sodium sulphite $\left(\mathrm{Na}_{2} \mathrm{SO}_{3}\right.$, sigmaaldrich, $\left.\geq 98.0 \%\right)$, Zinc acetate $\left(\mathrm{Zn}\left(\mathrm{CH}_{3} \mathrm{COO}\right)_{2} \cdot 2 \mathrm{H}_{2} \mathrm{O}\right.$, Merck, 99.5\%), Selenium powder (Se, Acros, 99.5\%), Copper (II) nitrate $\left(\mathrm{Cu}\left(\mathrm{NO}_{3}\right)_{2} \cdot 3 \mathrm{H}_{2} \mathrm{O}\right)$ and Sulphur powder (S, VWR Chemicals, 99.5\%), Fluorine doped tin oxide (FTO) glass, $\mathrm{TiO}_{2}$ nanoparticle. All reagents and solvents were purchased from commercial sources and were used without further purification.

Preparation of CdS/CdSe $/ \mathrm{Ho}^{3+}$ Solar Cells: First, we deposited a thin film of $\mathrm{TiO}_{2}$ on FTO transparent conductive layer According to doctor blade method. Secondly, the electrode was heated up to $125^{\circ} \mathrm{C}$ for 6 minutes and then cool down to $25^{\circ} \mathrm{C}$. This process was repeated until a desired thickness was achieved. To prepare $\mathrm{X}$ electrode, $\mathrm{TiO}_{2}$ photoanodes were placed in a $10 \mathrm{~mL}$ of cadmium nitrate solution (1.17g in water) for 5 minutes and then were washed with distilled water. Then, $\mathrm{TiO}_{2}$ photoanodes were immersed in a $10 \mathrm{~mL}$ solution containing $2.14 \mathrm{~g}$ sodium sulfide for 5 minutes. This cycle was repeated for three times. The resulting electrode was used as the control electrode. To prepare Y photoanode, plunge a photoanode was immersed in a $10 \mathrm{~mL}$ of solution with $1.17 \mathrm{~g}$ of dissolved cadmium nitrate and $0.284 \mathrm{~g} \mathrm{Ho}^{3+}$ for 5 minutes, and then the sample was dried. The sample is added to the solution of $2.4 \mathrm{~g}$ of $\mathrm{Na}_{2} \mathrm{~S}$ per $10 \mathrm{~mL} \mathrm{H}_{2} \mathrm{O}$. This cycle was repeated for 3 times. The electrodes were dried at room temperature. Based on reported synthesis by Samadpour et al. [19]. In order to prepare CdSe, $1.26 \mathrm{~g}$ of sodium sulfite and $0.315 \mathrm{~g}$ of selenium powder was refluxed in $50 \mathrm{~mL}$ of distilled water under nitrogen gas for 5 hours at a temperature of $80-85^{\circ} \mathrm{C}$ at $400-500 \mathrm{rpm}$.

The result is the formation of sodium selenosulphate (Solution of a). According to Figure 2, different solutions with different volumes were prepared. $1.2 \mathrm{~g}$ of cadmium sulphate were dissolved in $50 \mathrm{~mL}$ of distilled water. Separately, $1.40 \mathrm{~g}$ of sodium hydroxide was dissolved in $10 \mathrm{~mm}$ of distilled water. Moreover, $1.65 \mathrm{~g}$ nitriloacetic acid was dissolved in $40 \mathrm{~mL}$ of distilled water in a round-bottom flask and then three samples were mixed and finally added to the b solution (Figure 2). The final products of $\mathrm{a}$ and $\mathrm{b}$ was placed in a beaker of $200 \mathrm{~mL}$. The synthesized electrodes were kept away from sunlight for 15 to 18 hours at 2 to $3^{\circ} \mathrm{C}$, Ultimatelly, the electrodes were washed with distilled water (Figure 3). The electrode immersed in a solution consist of $0.219 \mathrm{~g}$ of zinc acetate, $10 \mathrm{~mL}$ of distilled water and $0.24 \mathrm{~g}$ sodium sulfide $\mathrm{Na}_{2} \mathrm{~S}$. This cycle was repeated three times. FTO glass was immersed in an aqueous solution of $1.2 \mathrm{~g}$ copper nitrate in $10 \mathrm{~mL}$ of distilled water for 30 seconds and then was washed with ethanol. This cycle was repeated for 5 times. Finally a black thin layer of CuS appeared on FTO. Three aqueous solutions containing $1.2 \mathrm{~g} \mathrm{Na}_{2} \mathrm{~S}, 0.16 \mathrm{~g} \mathrm{~S}, 0.2 \mathrm{~g} \mathrm{NaOH}$ were prepared separately and $5 \mathrm{~mL}$ of each solution was mixed in a round-bottom flask for 90 minutes at the room temperature.

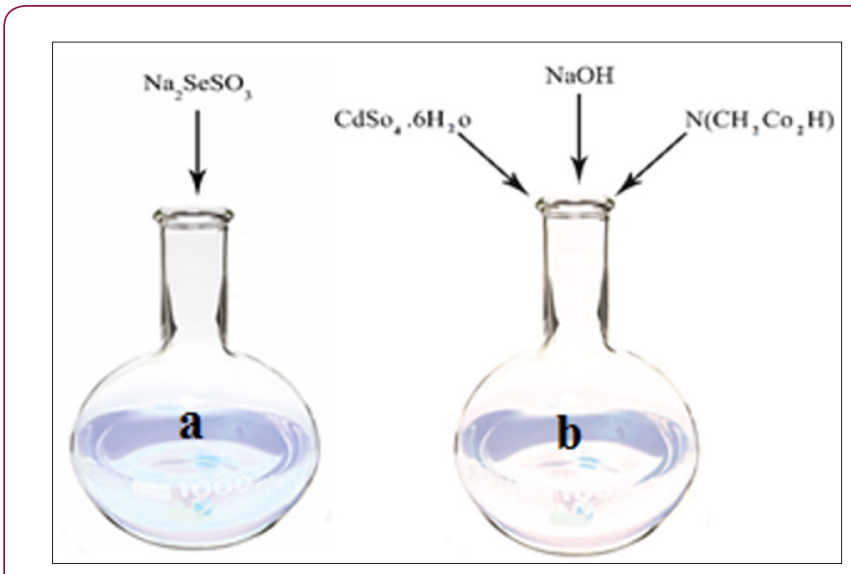

Figure 2: Preparation of a solution (sodium sulfite+ selenium powder) and $b$ solution (cadmium sulphate+ sodium hydroxide+ nitriloacetic acid).

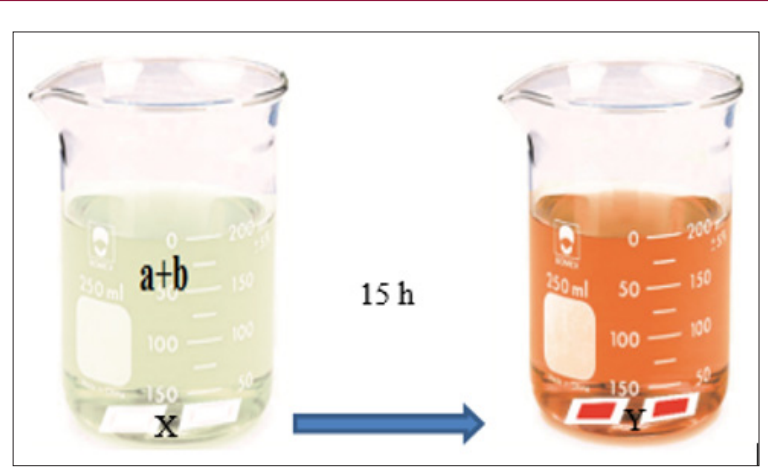

Figure 3: $X$ (blank) and $Y($ Ho doped on $X)$ electrodes in solution of $\mathrm{a}+\mathrm{b}$.

\section{Results and Discussion \\ SEM}

To determine the particle sizes in anodic sub-layer coated by a layer of $\mathrm{TiO}_{2}(20-40 \mathrm{~nm})$ and to measure the thikness of the layer's SEM-EDX analysis was performed. (Figure 4a) shows SEM image of $\mathrm{TiO}_{2}$ layers (20 to $400 \mathrm{~nm}$ ) that indicates a porous surface and uniform particle size. The diameters of first and second layers are estimated to be $3.77 \mu \mathrm{m}\left(\mathrm{TiO}_{2}-400 \mathrm{~nm}\right)$ and $4.72 \mu \mathrm{m}\left(\mathrm{TiO}_{2}-200 \mathrm{~nm}\right)$ respectively. SEM images in Figure $4 \mathrm{~b}$ shows that surface morphology has been changed in the presence of CdS/CdSe quantum dotes and shiny dots with $500 \mathrm{~nm}$ size is appeared that can be related to $\mathrm{CdS} / \mathrm{CdSe}$ quantum dotes. The diameter of first and second layers have changed to $4.03 \mu \mathrm{m}$ and $4.27 \mu \mathrm{m}$, respectively. Finally, the 
thicknesses of $\mathrm{TiO}_{2}$ layers are shown to be $4.04 \mu \mathrm{m}$ and $6.32 \mu \mathrm{m}$ for first and second layers in Figure 4c, respectively.
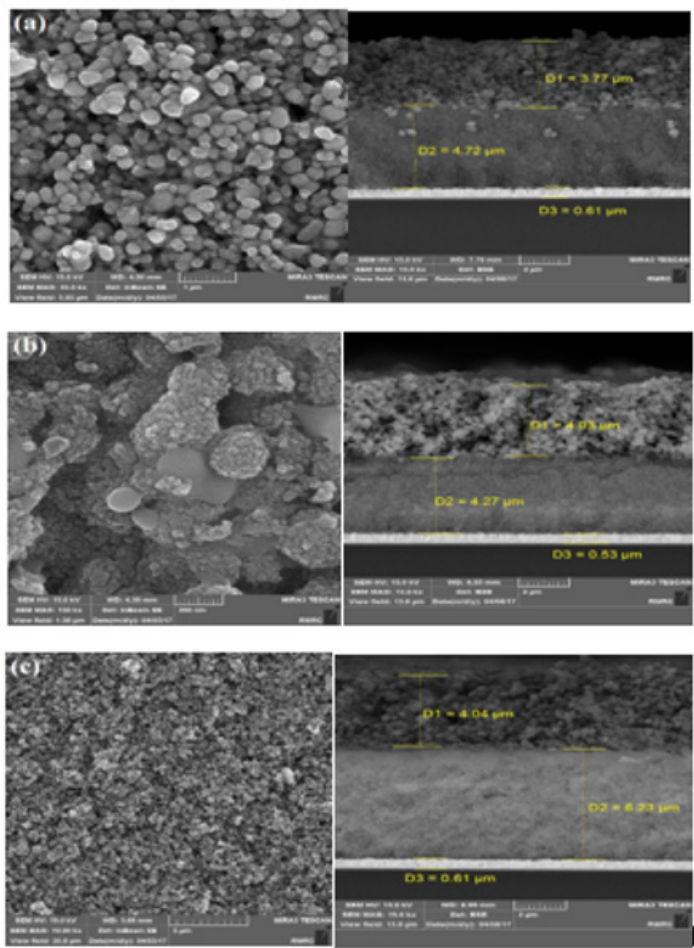

Figure 4: SEM image.

Note:

a) $\mathrm{TiO}_{2}$ film (20 to $400 \mathrm{~nm}$ ) and cross-sectional view,

b) $\mathrm{TiO}_{2}$ film CdS/CdSe QDs and cross-sectional view, and

c) $\quad \mathrm{TiO}_{2}$ film CdS/CdSe/ $\mathrm{Ho}^{3+}$ and cross-sectional view.

\section{EDX}

EDX analysis determined the amount of element such as $\mathrm{Se}=8.82, \mathrm{~S}=2.4$ and $\mathrm{Cd}=14.57$. MAP cleared that $\mathrm{Cd}$ spread uniformly on the surface of $\mathrm{TiO}_{2}$. Amount of $\mathrm{Ho}^{+3}$ existent $(0.46 \mu \mathrm{m})$ confirms the SEM images even though it's less than amount of $\mathrm{Cd}$ (Figure 5).

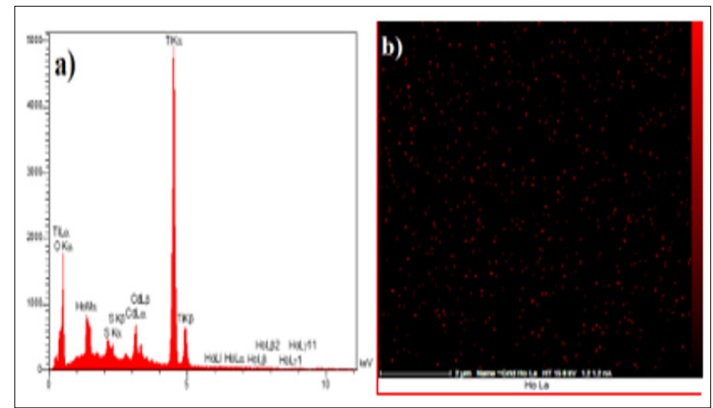

Figure 5: EDX spectra.

Note:
a) $\mathrm{CdS} / \mathrm{CdSe} / \mathrm{Ho}$ and
b) $\mathrm{Ho}^{3+}$ mapping.

\section{Photovoltaic (JV) Performance Studies}

Undoped and $\mathrm{Ho}^{3+}$ doped samples with different concentrations $(50,75$ and $150 \mathrm{mM})$ were radiated by solar simulator (AM 1.5). Results are shown in Table 1. Results demonstrate that $\mathrm{Ho}^{3+}$ doped samples show higher efficiency than undoped samples, consequently the experiment in $150 \mathrm{mM}$ concentration has been repeated for two times and concluded that the better efficiency was related to $\mathrm{Ho}^{3+} 150 \mathrm{mM}$ concentration (Figures $6 \& 7$ ) and (Table 2).

Table 1: Efficiency of solar cells with different percentages.

\begin{tabular}{|c|c|c|c|c|}
\hline aSample (mM) & $\mathbf{V}_{\mathbf{o c}}(\mathbf{V})$ & $\mathbf{J}_{\mathbf{s c}}\left(\mathbf{m A} / \mathbf{c m}^{-2}\right)$ & $\mathbf{F F}$ & $\mathbf{h}(\mathbf{\%})$ \\
\hline Blank & 0.44 & 3.94 & 0.5 & 0.87 \\
\hline 50 & 0.48 & 7.32 & 0.44 & 1.56 \\
\hline 75 & 0.58 & 12.61 & 0.26 & 1.94 \\
\hline 100 & 0.49 & 9.58 & 0.45 & 2.12 \\
\hline
\end{tabular}

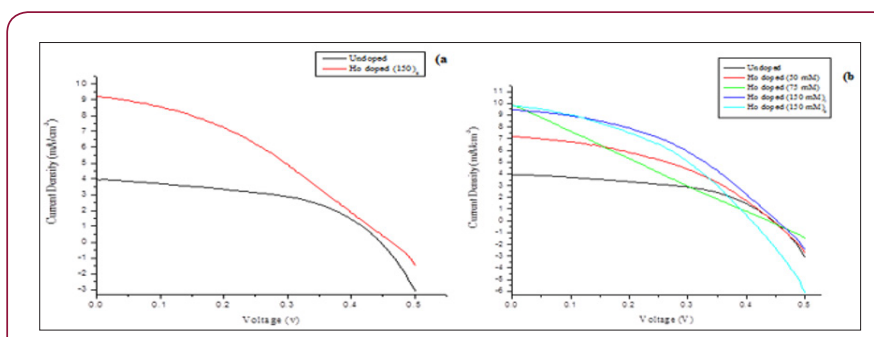

Figure 6: (a) Related to the optimum $\mathrm{Ho}^{3+}$ concentration in comparison with blank. (b) related to the optimum prepared cells efficiency in comparison with blank.

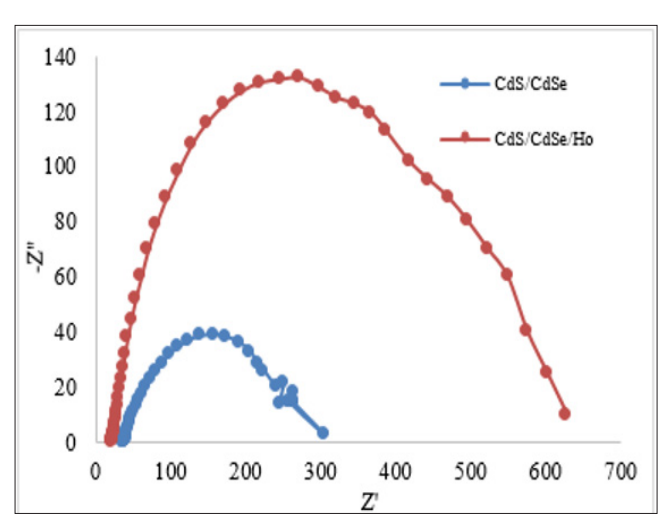

Figure 7: Electrochemical impedance spectra of the CdS/ CdSe and CdS/CdSe/Ho.

Table 2: The yield doped samples compared to blank samples.

\begin{tabular}{|c|c|c|c|c|}
\hline aSample (mM) & $\mathbf{V}_{\mathbf{~ o c}}(\mathbf{V})$ & $\mathbf{J}_{\mathbf{s c}}\left(\mathbf{m A} / \mathbf{c m}^{-2}\right)$ & $\mathbf{F F}$ & $\mathbf{h}(\mathbf{\%})$ \\
\hline Blank & 0.44 & 3.94 & 0.5 & 0.87 \\
\hline $150(1)$ & 0.5 & 10.14 & 0.44 & 2.28 \\
\hline $150(2)$ & 0.6 & 9.67 & 0.43 & 2.53 \\
\hline
\end{tabular}

\section{Electrochemical Impedance Spectroscopy (EIS)}

Figure 7 shows the electrochemical impedance spectra (EIS) of the CdS/CdSe and CdS/CdSe/Ho. Nyquist curves obtained from EIS measurements were fitted with equivalent circuit model as shown in Figure 7. Recombination resistance (Rre) of CdS/CdSe and CdS/ 
CdSe/Ho samples are $263.30 \Omega$ and $628.23 \Omega$, respectively, which means the electrons and holes recombination in the Ho-doped $\mathrm{CdS} / \mathrm{CdSe}$ solar cells are less than that of CdS devices. Thus, the less charge recombination can be observed in $\mathrm{CdS} / \mathrm{CdSe} / \mathrm{Ho}$.

\section{Conclusion}

Doping of few amounts of $\mathrm{Ho}^{3+}$ ions improves electronic and photo-physical properties of quantum dots and creates an electronic level at the middle gap area. This electronic state changes charge separation and reduces electron-hole recombination. Changing in the type and amount of impurity causes different electronic and photonic properties of nanocrystal semiconductors. In this work, quantum dot solar cells were fabricated, and some investigations were performed on their structure and it was indicated that quantum yield increased from $0.87 \%$ to $2.53 \%$ by adding $\mathrm{Ho}^{3+}$ metal ion. Using $\mathrm{Ho}^{3+}$ for surface modification leads to increase in yield of solar cells which it can be concluded that adding lanthanides ions increase the performance of quantum dots because of electron transportation properties and these cases may increase quantum yield of nanoparticle solar cells.

\section{Acknowledgment}

We are grateful to the PNU for funding this work.

\section{References}

1. Prieto Pedro A, Charles AS Hall (2013) Introduction: Solar Energy and Human Civilization. Spain's Photovoltaic Revolution. Springer, New York, USA: 1-13.

2. Chen Haining, Zhu L, Liu H, Li W (2013) ITO porous film-supported metal sulfide counter electrodes for high-performance quantum-dotsensitized solar cells. J Phys Chem C 117(8): 3739-3746.

3. Lan X, Voznyy O, Kiani A, García de Arquer FP, Abbas AS, et al. (2016) Passivation using molecular halides increases quantum dot solar cell performance. Advanced Materials 28(2): 299-304.

4. Maclay B (2014) The new net zero: Leading-edge design and construction of homes and buildings for a renewable energy future. In Maclay B (Eds.) Chelsea Green Publishing, USA?

5. Kamat PV (2013) Quantum dot solar cells. The next big thing in photovoltaics. J Phys Chem Lett 4(6): 908-918.'

6. Ameen S, Akhtar MS, Seo HK, Nazeeruddin MK, Shin HS (2015) An insight into atmospheric plasma jet modified $\mathrm{ZnO}$ quantum dots thin film for flexible perovskite solar cell: optoelectronic transient and charge trapping studies. J Phys Chem C 119(19): 10379-10390.]

\section{ISSN: 2574-1241}

DOI: 10.26717/BJSTR.2018.11.002086

Ghasem Rezanejad Bardajee. Biomed J Sci \& Tech Res

This work is licensed under Creative Commons Attribution 4.0 License

Submission Link: https://biomedres.us/submit-manuscript.php
7. Klimov VI, Baker TA, Lim J, Velizhanin KA, McDaniel H (2016) Quality factor of luminescent solar concentrators and practical concentration limits attainable with semiconductor quantum dots. ACS Photonics 3(6): 1138-1148'.

8. Lin Q Yu HJ, Liu W, Song HJ, Makarov NS, et al. (2017) Phase-transfer ligand exchange of lead chalcogenide quantum dots for direct deposition of thick, highly conductive films. J Am Chem Soc 139(19): 6644-6653.]

9. Koh WK, Dandu NK, Fidler AF, Klimov VI, Pietryga JM, et al. (2017) Thickness-Controlled Quasi-Two-Dimensional Colloidal PbSe Nanoplatelets. Journal of the American Chemical Society 139(6): 21522155.

10. Yu H, Huang X, Wang P, Yu J (2016) Enhanced photoinduced-stability and photocatalytic activity of CdS by dual amorphous cocatalysts: synergistic effect of Ti (IV)-hole cocatalyst and Ni (II)-electron cocatalyst. J Phys Chem C 120(7): 3722-3730.

11. Mukherjee P, Lim SJ, Wrobel TP, Bhargava R, Smith AM (2016) Measuring and Predicting the Internal Structure of Semiconductor Nanocrystals through Raman Spectroscopy. J Am Chem Soc 138(34): 10887-10896.

12. Kundu S, Sarojinijeeva P, Karthick R, Anantharaj G, Saritha G, et al. (2017) Enhancing the Efficiency of DSSCs by the Modification of TiO2 Photoanodes using N, F and S, co-doped Graphene Quantum Dots. Electrochimica Acta 242: 337-343.

13.Zhang YZ, Wu ZZ, Pan GL, Liu S, Gao XP (2017) Microporous Carbon Polyhedrons Encapsulated Polyacrylonitrile Nanofibers as Sulfur Immobilizer for Lithium-Sulfur Battery. ACS Appl Mater Interfaces 9(14): 12436-12444.

14. Binnemans K, Jones PT (2017) Solvometallurgy: an emerging branch of extractive metallurgy. Journal of Sustainable Metallurgy 3(3): 570-600.

15. Cao DH, Stoumpos CC, Yokoyama T, Logsdon JL, Song TB, et al. (2017) Thin Films and Solar Cells Based on Semiconducting Two-Dimensional Ruddlesden-Popper (CH3 (CH2) 3NH3) 2 (CH3NH3) n- 1Snn I3 n+ 1 Perovskites. ACS Energy Lett 2(5): 982-990?

16. Guntlin CP, Zünd T, Kravchyk KV, Wörle M, Bodnarchuk MI, et al. (2017) Nanocrystalline FeF 3 and MF 2 (M= Fe, Co, and Mn) from metal trifluoroacetates and their Li (Na)-ion storage properties. J Mater. Chem A 5(16): 7383-7393.

17. Rasukkannu M, Velauthapillai D, Vajeeston P (2017) Computational modeling of novel bulk materials for the intermediate-band solar cells. ACS Omega 2(4): 1454-1462.]

18. Chakraborty S, Pal M (2017) Improved sensitivity of CdS nanoparticles by virtue of calcium doping: Promising candidate for monitoring alcohol in exhale human breath. Materials \& Design 126: 18-28.]

19. Samadpour M, Bardajee GR, Gheysare SG, Shafagh P (2015) Transition metal doping for enhancing quantum dot sensitized solar cells performance. Journal of Physics D: Applied Physics 48(9): 095101.

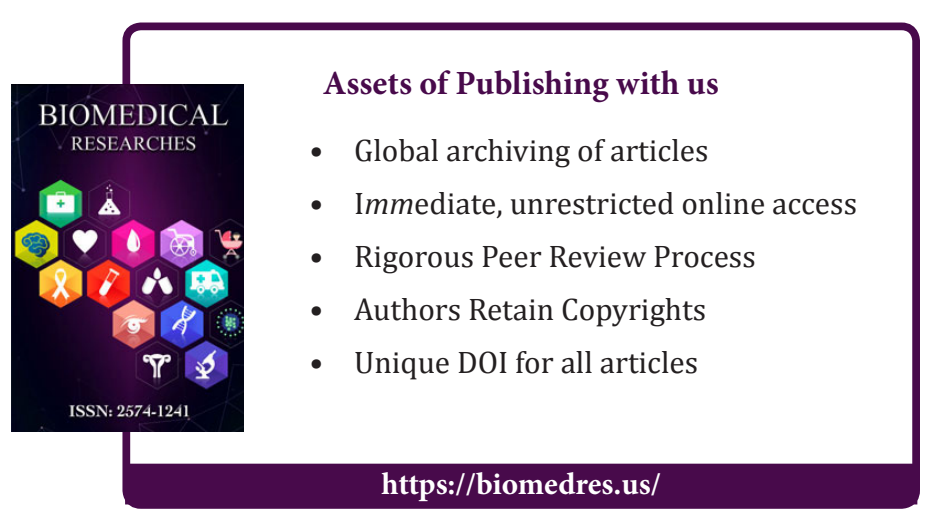

